technical journals are printed in these languages, and Russian itself is merely one of the more important subjects of instruction in the schools.

In the early years after the Revolution, schools for adults formed an important part of the Russian educational system, and were strongly supported by the State. Adult students numbered 320,000 in 1932 ; but the numbers are, of course, gradually declining, as the younger generation, much better educated than its forbears, is growing up. Among all classes of the population-old and young-there is a zeal and keenness for education, stimulated by the teachings of Lenin and other early leaders; but for some time there was a serious lack of suitable teachers. In 1939 the number of professorships or chairs was about 10,000, more than half of which were held in the technical and agricultural colleges; while the total teaching staff was a little more than 40,000. Education is mostly entirely free, and some 90 per cent of the students of college grade schools receive grants.

Special attention is, of course, devoted to vocational training, and the aim is to give at least a minimum of technical training to every worker, including labourers. The Five-Year Plan ending 1942 called for the training of more than 9 million persons for work in industry in different capacities. The technical schools in the Soviet Union, in addition to the higher college grade schools or universities, include also the 'technicums' or secondary technical schools. In 1938 there were in existence 3,400 of these, and it was expected that the number of students would reach 800,000 in 1942. For admission to a 'technicum', seven years of preliminary schooling is required, as compared with ten years for the college grade school ; and the course lasts four years.

The factory schools fulfil important functions in training qualified workers. They were reconstituted in a different form in 1940. During the first FiveYear Plan these schools trained 450,000 workers; treble that number during the second; and the number planned for the third was $1,700,000$. In addition to purely vocational training, they give a certain amount of general and political education, and also special training designed to meet the needs of any particular industry.

Special facilities, largely controlled by the Committee for Higher Education in Moscow, are provided for a first-class engineering training for students who have taken the general courses in secondary schools and have reached the age of 19-20. These are available either in the universities or technical colleges, and extend over five years, with examinations every year. The programme of study comprises almost the same basic subjects as those of engineering schools in other countries, with a few exceptions. In the case of non-Russian students, ample provision is made for the study of Russian for the first two years, the time being taken out of that allotted for foreign languages. Social and economic science and philosophy are included, with particular reference to that of the Communist Party. Parentheticelly, it may be remarked that this philosophy is not necessarily the same as it was in the early days : one of the points most strongly emphasized by Lenin was that social philosophy must be constantly subject to change and evolution, and this appears to have been confirmed in the recent history of the Soviet Union. In regard to foreign languages, it is interesting to note that, until lately at all events, English was the foreign language to be studied by petroleum engineers, whereas German was preferred for mechanical engineers.

Special efforts are made to provide sufficient numbers of the right kind of fully trained teachers for the engineering courses ; and no money is spared in buildings and equipment, in facilities for research, and so forth. More attention also is now being given to the matter of patents for invention, with the view of making the patent system a more effective means of encouragement in developing the inventive skill or genius of students. Employment bureaux are an essential part of the organization, but their chief difficulty is that there are always more positions open than applicants to fill them. The 150,000 young engineers and scientific agriculturists trained in more than two hundred technical colleges during the third planned period were certain to be less than the number required. Provision is also made for postgraduate work and preparation for D.Sc., D.Ph. and other degrees. In view of the shortage of trained men just mentioned and the vast programme of rebuilding, etc., at the end of the War, it is thought there may be scope and opportunity for collaboration with British and American engineers, and no doubt this is already under careful consideration in the right quarters.

\section{NATIONAL RESEARCH COUNCIL, CANADA}

THE twenty-sixth annual report of the National Research Council, Canada, 1942-43, includes the report of the president together with the reports of the directors of the Divisions of Applied Biology, Chemistry, Mechanical Engineering, Physics and Electrical Engineering, of the Section on Codes and Specifications and of the Research Plans and Publications Section. Owing to war-time requirements, publication of the "Review of Activities" has been discontinued temporarily. The National Research Council is now serving as a central co-ordinating body directing scientific research in Canada, within its own laboratories, in the universities and in industry, and the Council has been appointed the official research station of the Navy, Army and Air Force in Canada.

With the exception of a long-term project on forest-tree breeding, the work in the Division of Applied Biology is now wholly related to the war effort. The pre-war staff of nine has been increased to twenty-nine to cope with the food problems submitted by various Government departments. Investigations on modified curing practices have led to the adoption of a standard cure, with the result that Canadian bacon is now held in higher favour on the British market than ever before, and even under war-time conditions of transport and storage the proportion of Canadian bacon de-graded by the British Ministry of Food is so exceptionally small that rigorous inspection is no longer considered necessary. Studies on egg-shell treatment to extend the storage life of eggs under the storage and transport conditions of war-time have been completed and large-scale investigations undertaken to determine the best conditions applicable in industry for processing and storing dried eggs. Standard canning procedures in line with the Council's findings have been adopted by manufacturers of canned pork and ham, and a laboratory method has been developed 
for processing Irish moss. Work is being continued to find a commercial method for preparing a good gelling substance from this seaweed. Work has been undertaken on improvement of the stability and other properties of lard as a suitable alternative for other vegetable oil shortenings. A survey was made of the vitamin intake of Canadian Army troops garrisoned at district depots, and much work has been done on the development of substitutes for metal containe tith special reference to the packaging of dehydrated foods for export or Army use. The Fermentation Section's staff has been increased from four to fourteen members, and much of the time of the Section has been devoted to the study of the manufacture of butylene glycol from wheat by a fermentation process. Pilot plant is under construction.

In the Division of Chemistry, research on photo. sensitized reactions has continued, but experimental alkaloid research has been on a reduced scale. Fundamental investigations on the chemistry of leather and plastics have continued, and that Section has been considerably enlarged to take care of the test work required by the Armed Services and Inspection Board. The laboratories of the Textile Section were occupied chiefly with defence work involving investigations on substitute materials and preparation of purchase specifications, acceptance tests and fundamental research on problems arising out of war uses of textiles. The Paint Laboratory has been occupied. to an increasing extent with the needs of the Services for special paints, lacquers, protective coatings, shellfilling material, anti-freezes, etc. The Rubber Laboratory has given special attention to the study of rubber substitutes and synthetic rubber.

In the Division of Mechanical Engineering, all work having no bearing on the war effort has been suspended or abandoned. Installation of the driving and controlling equipment of the horizontal wind tunnel has been completed, and calibration and adjustment of the vertical spinning tunnel are proceeding. The staff of the Division of Physics and Electrical Engineering has been further increased, and, as before, the bulk of the investigations have been of a secret nature and not at present suitable for publication. The General Physics Section has been engaged largely on naval work, ballisties and the design of fire-control gear, as well as on the development of equipment for one phase of antisubmarine warfare. Work in the Optics Section has involved research and development in optical instruments, photography, spectrochemical analysis and geometrical optics as well as the making of a large number of optical components of military instruments in the optical shop.

The Section on Codes and Specifications has been restricted during the War to a maintenance basis in respect of its two main branches-the National Building Code and the Canadian Government Purchasing Standards Committee. The Research Plans and Publications Section, which is responsible for the conduct of the National Research Council Library, refers to the increasing use of the Library, to its bibliographic work and literature searches, technical inquiry work and the issue of the Canadian Journal of Research.

Other details of the war work of the Divisions are included in the president's report, which also gives a survey of extra-mural activities of the Council. Among these may be specially mentioned the Service committees established under the Associate Com- mittee on Medical Research to deal with Aviation Medical Research, Naval Medical Research and Army Medical Research. The first has carried out an impressive programme of work in the fields of highaltitude flying, protective clothing for flyers, oxygen equipment and in special studies relating to personnel selection. The second, in addition to dietary surveys in vessels under operating conditions and in shore establishments, has carried out experiments on the use of vitamin $\mathbf{A}$ to improve night vision. Special lighting techniques designed to minimize interference with night vision have been devised for use on bridge controls, bridge instruments and chart tables. Special tests elaborated for the evaluation of night vision, colour vision, and visual acuity have been adopted. by the Navy, while experimental work on fatigue of personnel operating anti-submarine detection devices has yielded information which has been applied in determining the watch period to be used for this work. Other investigations have covered underwater blast injury, eye-protection for bridge and look-out personnel, obtaining fresh water from seawater in lifeboats, protection of naval personnel from noise, combating fatigue in radio detector and wireless operators, and sea-sickness problems. Another war-time committee of the Council has co-ordinated and directed research in Canadian universities on sixty projects concerned with the production of explosives now in use and the development of new explosives.

\section{THIRD ANNUAL MEETING OF THE ANTI-FASCIST SOCIETY OF SOVIET SCIENTISTS \\ By VICTOR KRASILNIKOV*}

DROMINENT representatives of Soviet science Pattended the third meeting of the Anti-fascist Society of Soviet Scientists held in Moscow on June 18. In his opening remarks, the president, Derzhavin, reminded his audience of the solemn oath taken by them at their first meeting in the memorable days of October 1941 when the German Army was driving on to the capital of the U.S.S.R. They then vowed to devote all their energy and knowledge to the war effort of the nation. Soviet men of science, he said, have kept that vow.

An eloquent speech was made by the vice-president of the Academy of Sciences, Alexander Baikov. $\mathrm{He}_{\mathrm{e}}$ gave an account of the great contributions of Soviet men of science to the war effort. Metallurgists have speeded up existing processes of production, and introduced important improvements in the technology of iron and steel production. Geologists have discovered new deposits of manganese, mercury, lead and petroleum. Botanists have investigated new varieties of medicinal herbs and vitamin-yielding plants. Agricultural scientists have helped to increase crop-yields. Medical scientists have shown numerous examples of self-sacrificing service to their country.

Prof. Peter Kapitza, of the Academy of Sciences, remarked that since the second meeting of the Society, in July 1943, many stirring and cheering events have taken place. But, while rejoicing at the Army's advance, in the course of which Russian territory is being liberated from the hands of the

\footnotetext{
* Transcribed and prepared by $\Lambda$. Clifford.
} 